\title{
RELATIVE AGE IN FEMALE FUTSAL ATHLETES: \\ IMPLICATIONS ON ANTHROPOMETRIC \\ PROFILE AND STARTER STATUS
}

IDADE RELATIVA EM ATLETAS DE FUTSAL FEMININO: IMPLICAÇÕES NO PERFIL ANTROPOMÉTRICO

ARTIGO ORIGINAL

E TITULARIDADE

EDAD RELATIVA EN ATLETAS DE FUTSAL FEMENINO: IMPLICACIONES EN EL PERFIL ANTROPOMÉTRICO

YTITULARIDAD

Sandra Aires Ferreira', (DD

(Physical Education Professional)

Matheus Amarante do

Nascimento 2,3 (D)

(Physical Education Professional)

Timothy Gustavo Cavazzotto 1,2 (DD (Physical Education Professional)

Vinícius Müller Reis Weber ${ }^{1,2}$ (D)

(Physical Education Professional)

Marcus Peikriszwili Tartaruga' (DD

(Physical Education Professional)

Marcos Roberto Queiroga ${ }^{1,2}$ (ID)

(Physical Education Professional)

1. Universidade Estadual do Centro Oeste (UNICENTRO), Guarapuava, PR, Brazil.

2. Associate Postgraduate Program in Physical Education (UEL/UEM)

Londrina, PR, Brazil.

3. Universidade Estadual do Paraná

- UNESPAR, Paranavaí Campus,

$P R$, Brazil.

\section{Correspondence:}

\begin{abstract}
Introduction: Evidence suggests that a higher distribution of elite athletes have birth dates in the first few months of the year. However, the advantages of birth month on performance related to starter status, structure and body composition in female futsal (5-a-side football played on a hard court, mainly indoors), are unknown. Objective:To determine the effect of relative age (ERA) on competitive female futsal athletes, and its influence on anthropometric profile and starter status. Methods: One hundred and fifteen athletes, participants in the 20th Brazilian Cup of Adult Futsal Clubs, special division, were submitted to measurements of body mass, height, skinfold thickness, body perimeters and bone diameters, in order to characterize the anthropometric profile and determine the body somatotype. The athletes were distributed in semesters and quartiles of the months of the year, according to their birth dates. Differences in the distribution of expected and observed birth dates were tested using Chi-square tests $\left(x^{2}\right)$. Comparisons between semesters and birth quartiles were performed using parametric and non-parametric tests. Results: There was no ERA in distribution $(p=0.248$ ), anthropometric profile ( $p=0.872$ to 0.912 ), or starter status between athletes born from January to June $(p=0.352)$ and those born between July and December $(p=0.744)$. On the other hand, those born in the first months of the year showed longer practice times than those born in the latter months of the year. Conclusion: Although the ERA in this study reveals longer practice times favoring female futsal athletes born in the first quartile of the year, it did not influence the starter status, the distribution in the teams, or any advantage in anthropometric profile. Level of evidence III, Case-Control Study.
\end{abstract}

Keywords: Birth semester; Date of birth; Practice time; Futsal; Physical activity; Relative age.

\section{RESUMO}

Introdução: Evidências sugerem maior distribuição de atletas de elite com data de nascimento nos primeiros meses do ano. Entretanto, as vantagens que o mês de nascimento exerce no desempenho relacionado à titularidade, estrutura e composição corporal no futsal feminino são desconhecidas. Objetivo: Determinar o efeito da idade relativa (EIR) em atletas de futsal feminino competitivo e sua influência no perfil antropométrico e na titularidade. Métodos: Cento e quinze atletas, participantes da XXTaça Brasil de Clubes de Futsal Feminino Adulto, divisão especial, foram submetidas a medidas de massa corporal, estatura, espessuras de dobras cutâneas, perímetros corporais e diâmetros ósseos, a fim de caracterizar o perfil antropométrico e determina r o somatotipo corporal. As atletas foram distribuidas em semestres equartis dos meses do ano, de acordo com suas datas de nascimento. Diferenças na distribuição das datas de nascimento esperadas e observadas foram comparadas utilizando o teste de qui-quadrado $\left(X^{2}\right)$. As comparações entre os semestres e os quartis de nascimento foram realizadas utilizando os testes paramétricos enão paramétricos. Resultados: Não houve EIR na distribuição $(p=0,248)$, no perfil antropométrico ( $p=0,872$ a 0,912) ou na titularidade entre as atletas nascidas de janeiro a junho $(p=0,352)$ e as nascidas entre julho a dezembro $(p=0,744)$. Por outro lado, as atletas nascidas nos primeiros meses do ano demonstraram maior tempo de prática do que as nascidas nos últimos meses do ano. Conclusão: Apesar do ElR neste estudo revelar maior tempo de prática favorecendo atletas de futsal feminino nascidas no primeiro trimestre do ano, não influenciou a condição de titular, a distribuição nas equipes, ou qualquer vantagem no perfil antropométrico. Nível de evidência III, Estudo Caso-Controle.

Descritores: Semestre de nascimento; Data de nascimento; Tempo de prática; Futsal; Exercício físico; Idade relativa.

\section{RESUMEN}

Introducción: Evidencias sugieren mayor distribución de atletas de élite con fecha de nacimiento en los primeros meses del año. Entretanto, las ventajas que el mes de nacimiento ejerce sobre el desempeño relacionado a la titularidad, estructura y composición corporal en el futsal femenino son desconocidas. Objetivo: Determinar el efecto de la edad relativa (EER) en atletas de futsal femenino competitivo y su influencia en el perfil antropométrico y en la titularidad. Métodos: Ciento quince atletas, participantes de la XX Copa Brasil de Clubes de Futsal Femenino Adulto, división especial, fueron sometidas a medición de mas a corporal, estatura, espesores de los pliegues cutáneos, perímetros corporales y diámetros óseos, a fin de caracterizar el perfil antropométrico y determinar el somatotipo corporal. Las atletas fueron distribuidas en semestres y cuartiles de los meses 
del año, de acuerdo con sus fechas de nacimiento. Las diferencias en la distribución de las fechas de nacimiento esperadas y observadas fueron probadas usando el test de chi cuadrado ( $x^{2}$ ). Las comparaciones entre los semestres y los cuartiles de nacimiento realizadas usando tests paramétricos y no paramétricos. Resultados: No hubo EER en la distribución $(p=0,248)$, en el perfil antropométrico $(p=0,872$ a 0,912) o en la titularidad entre atletas nacidas de enero ajunio $(p=0,352)$ y las nacidas entre julio a diciembre $(p=0,744)$. Por otro lado, las atletas nacidas en los primeros meses del año demostraron mayor tiempo de práctica que las nacidas en los últimos meses del año. Conclusión: Aunque el EER en esteestudio revela un tiempo de práctica más prolongado que favorece a las atletas de futsal femenino nacidas en el primer trimestre del año, no influyó en la posición inicial, la distribución en los equipos ni ninguna ventaja en el perfil antropométrico. Nivel de evidencia III, Estudio Caso-Control.

Descriptores: Semestre de nacimiento; Fecha de nacimiento; Tiempo de práctica; Futsal; Ejercicio físico; Edad relativa.

\section{INTRODUCTION}

Until reaching the professional level, most of the children and young people involved with competitive sports activities are selected and categorized by age group. The selection of athletes in the base categories is performed by grouping according to the date of birth, between January $1 \mathrm{st}$ and December $31 \mathrm{st}$, that is, the categories are defined from the date of birth or chronological age. The fact that this classification system does not consider characteristics of growth and development of the participant can result in disadvantages for athletes who were born in the last months of the year when compared to athletes born in the initial months of the same year. In this sense, when some groups of athletes are distributed by quartile or half-year, tendentious distributions have been observed with relatively older individuals born in the first months of the selection year. ${ }^{1}$ This phenomenon is known as the effect of relative age (ERA) in sport and is characterized by the disproportionate frequency of successful athletes born in the first three months of the selection year. ${ }^{2}$

The information on the ERA reveals that athletes born in the first semester of each year are more represented in competitions, ${ }^{3}$ have better tactical performance ${ }^{4}$ and they are the majority among athletes that integrate selections ${ }^{5}$ than those born in the second semester. Other studies show that older athletes, born in the same year, have advantages from greater physical and cognitive development, increased stature, body mass and physical abilities. ${ }^{6-9}$

While some researchers point out that children and adolescents born in the first months of the year benefit from more developed physical attributes, which facilitates their recruitment to high level structures, ${ }^{10}$ others point to advantages from the longer exposure time to the teaching-learning-training process and / or the more advanced maturation stage. ${ }^{11}$ The greater time of practice in the modality and in other motor activities can translate into greater experience, psychological conditions, self-esteem and confidence, as well as better levels of perceptive and cognitive abilities. ${ }^{11}$ On the other hand, athletes born in the last months of the year (younger) are subject to reduced possibility of sports promotion due to physical, physiological, mental and emotional immaturity. ${ }^{12}$ In addition to these characteristics, the lower competitive capacity and motor development have been used to justify an increase in the rate of abandonment of sports practice among athletes born in the second semester. ${ }^{13}$ Contrary to this reasoning, Hancock, Adler and Cotê $^{14}$ argue that the role of social agents (parents, coaches, athletes) are more influential in sport ERA than maturational aspects. Although there is strong evidence of the ERA in sport, it is interesting to note that its influence can be mediated and dependent on age and sex. In this sense, research demonstrates that the ERA is significant for men and young athletes and not influential for older athletes and women., ${ }^{1,15}$ Conflicting results on the influence of relative age on the female gender suggest complex interactions for maturational and biological differences, sport onset, selection criteria, and sporting popularity. ${ }^{10,16}$ Although sport ERA has not been identified in some studies involving female samples, ${ }^{10,16,17}$ it has been confirmed in other studies. ${ }^{18,19}$

It is a fact that the great majority of the research involving ERA in the sport was developed with male athletes. ${ }^{8}$ In addition to the evident lack of information from the ERA in female athletes, its influence on physical development, such as body mass, height, fat mass, somatotype, as a starter or backup of a team and in the distribution of athletes in the female futsal. Thus, the present study had the objectives of verifying the ERA in the distribution, anthropometric profile and ownership in female competitive futsal athletes.

\section{METHODS}

\section{Participants}

The sample consisted of 115 female futsal players from 10 special division teams, who participated in the 20th Brazilian Women's Futsal Cup that occurred in Criciúma (03 to 09 October 2011). It is one of the most traditional competitions of the Brazilian Confederation of Futsal (CBFS) and gathered, in this edition, nine teams champion of the states, plus the team of the main city. The number of teams and state representation were: Paraná (1), São Paulo (1), Rio Grande do Sul (1), Santa Catarina (2), Brasília (1), Goiás (1), Pará (1), Ceará (1) e Bahia (1). The competition is annual and the first edition of the Brazilian Women's Futsal Cup was held in 1992.

Before data collection, the athletes and technicians received information about the intentions of the study and, after being informed, signed a free and informed consent form. The project was approved by the institutional review board (protocol \# 039/2011).

\section{Procedures for data collection}

Athletes and technicians were submitted to data collection procedures at different times, in order to obtain personal and specific information about their functions. Before the anthropometric measurements, the athletes answered questions such as: "What is your date of birth?", "What is your position / position on the court?", "How many hours of training per week?", "How long have you been practicing Futsal?", "When a game starts, are you related as a starting player, that is, start the game or enter during the game?".

It is worth mentioning that some athletes declared that they changed ownership with another one in most games, in turn, this and other information that characterized the athletes in the training and games, were confronted and confirmed later with the technicians who answer questions such as: "Who are their starter athletes?", "What position do the athletes play?", "How many hours of training per week?". From this information, the participants were grouped according to their playing conditions, that is, starters $(n=60)$ and backups $(n=55)$. The method of retrospection was used to estimate the age of menarche, which consisted, during the collection of personal information, asking if the 
menarche had occurred, as all affirmed positively, complemented by asking what day, month and year.

The evaluation of the memory of the age of menarche was made using the following indications: a) all certainty (for day, month and year), b) certainty (for month and year) and c) without certainty. Three athletes did not remember (indicated item " $c$ ") and were excluded from the study ( $n=112)$. To assist in remembering, we added to the question dates and merchant events like carnival, end of year, birthdays, etc. From the date of birth and date of the menarche, the age of menarche was calculated in decimal age.

Afterwards, the participants were submitted to a routine of measurements (body mass, height, thickness of the skinfolds, bone diameters and body circumferences) to characterize the anthropometric profile. The measures necessary for the determination of the somatotype were obtained in accordance with the guidelines of Marfell-Jones et al., ${ }^{20}$. A Cescorf ${ }^{\circledR}$ brand compass was used to measure skinfold thickness. Body mass was verified using an anthropometric scale (Welmy ${ }^{\circledR}$ ) with precision of $100 \mathrm{~g}$ and height was determined by means of a wooden stadiometer with measuring scale in 0,1 cm. Body mass index (BMI) was calculated from body mass and height, The perimetry measurements were collected with a flexible tape measure (Mabis $\left.{ }^{\circledR}\right)$ and bone diameters with a metal caliper (Somet ${ }^{\circledR}$ ). Body density was determined by regression equation with three skinfold thickness in the tricipital, suprailiac and thigh regions. ${ }^{21}$ The relative body fat (\%fat) was calculated from the formula proposed by Siri.22 Lean body mass and fat mass were determined in kg as follows: lean body mass = body mass - fat mass; Fat mass $=(\% \mathrm{fat} / 100) \times$ body mass. The calculation of the somatotype was obtained from the proposal modified by Heath and Carter, ${ }^{23}$ classifying the athletes in endomorph, mesomorph and ectomorph. All measurements were performed by an experienced assessor. Anthropometric variables were checked in duplicate in the right hemisphere of the body. If the difference was greater than $0.2 \mathrm{~mm}$ for skinfolds, or $0.5 \mathrm{~cm}$ for other variables, a third measurement would be performed. The final result used for data analysis was the average of two or three measurements. The competition's form of competition allowed each team to take one day off. In this sense, the data collection was performed in a room, in the same gym where the games were played and coincided with this day off of the teams, which allowed a minimum interval of $15 \mathrm{~h}$ between the last game and the evaluation.

\section{Statistical analysis}

Statistical analysis was performed using a commercial statistical package (SPSS version 18.0 - IBM Corporation, Armonk, NY, USA), adopting a significance level of $p<0.05$. By means of the date of birth, the athletes were separated in two (birth semester, Table 1) or four groups (birth quartile, Table 2). Initially, Shapiro Wilk test was used for an analysis of the distribution of the data by semester and birth quartile. For the semester of birth, the variables of weekly training and humerus diameter were not normal, while for the quartile of birth, only hours of training. Variables that presented normal values were expressed as mean and standard deviation (mean $\pm \mathrm{SD}$ ). The comparison between the two groups, first semester (January to June) and second semester (July to December) was performed from the t test for independent samples, while the comparison between the four groups, first quartile (Q1, January, February and March), second quartile (Q2, April, May and June); third quartile (Q3, July, August and September) and fourth quartile (Q4, October, November and December) was performed by analysis of variance (ANOVA). For the variables where there was no normality, the values were expressed as median and interquartile range (25-75\%). The comparison between the two groups (weekly training and humerus diameter) was performed from the Mann-Whitney $U$ test (semester) and, among the four groups (quartile). Kruskal-Wallis test was used for independent samples (training weekly). The distribution found in the semesters or birth quartiles was compared using the Chi-square test $\left(\chi^{2}\right)$ (Table 2 ).

\section{RESULTS}

Table 1 shows the distribution of futsal athletes, age, menarche age, sport start, practice time and weekly training hours, as well as anthropometric characteristics, considering the total sample (115 athletes) and per semester of birth (59 born in the first semester and 56 in the second). A little more than half (51.3\%) of the athletes in this study were born in the first semester and, similar to age, age of menarche, hours of training per week and anthropometric measurements, did not show differences between the two groups (semesters). Although the age of onset in the modality did not differ between births (12.6 \pm 3.7 vs. 13.4 \pm 3.4 years, respectively), there was a significant difference $(p=0.014)$ in the experience time in the modality, that is, the practice time (years) favored the athletes who were born in the first semester in approximately a year and a half. The values of the components of the somatotype did not differ between the semesters of birth and suggested a mesomorpho-endomorph profile, that is, a balance between the components fat mass and lean body mass.

Table 2 shows the same variables presented in table 1, however, with the athletes distributed in quartiles of birth. There was no REA in the distribution of the athletes between the birth quarters, except for the practice time in the modality, which showed significantly higher values (approximately 3 years) for the athletes born in the first three months (Q1), when compared to the athletes born in the last three months of the same year $(Q 4)(p=0.040)$, no other variable differed between birth quartiles.

Table 3 shows the distribution of female futsal athletes by semester and quartile of birth, considering the game condition, that is, if they are backups or starters of the teams. The information confirms that there is no significant advantage of the athletes born in the first months when compared to the athletes born in the last months of the year to the

Table 1. General characteristics of female futsal athletes according to the semester of birth.

\begin{tabular}{|c|c|c|c|c|}
\hline Variables & $\begin{array}{c}\text { All } \\
(n=115)\end{array}$ & $\begin{array}{c}\text { 1st semester } \\
(n=59)\end{array}$ & $\begin{array}{c}\text { 2nd semester } \\
(n=56)\end{array}$ & $p$ \\
\hline Relative distribution $(\%)^{\dagger}$ & 100 & 51.3 & 48.7 & 0.780 \\
\hline Age (years) & $22.0 \pm 3.9$ & $22.5 \pm 4.2$ & $21.4 \pm 3.5$ & 0.111 \\
\hline Body mass (kg) & $58.6 \pm 7.6$ & $58.1 \pm 7.6$ & $59.1 \pm 7.6$ & 0.508 \\
\hline Height (cm) & $161.8 \pm 6.5$ & $161.4 \pm 6.2$ & $162.2 \pm 6.9$ & 0.528 \\
\hline $\mathrm{BMI}\left(\mathrm{kg} / \mathrm{m}^{2}\right)$ & $22.3 \pm 2.1$ & $22.3 \pm 2.2$ & $22.4 \pm 2.0$ & 0.768 \\
\hline Menarche age (years) & $13.3 \pm 1.7$ & $13.4 \pm 1.7$ & $13.2 \pm 1.8$ & 0.602 \\
\hline Age of onset in futsal (years) & $13.0 \pm 3.6$ & $12.6 \pm 3.7$ & $13.4 \pm 3.4$ & 0.233 \\
\hline Practice time (years) & $9.0 \pm 4.3$ & $9.9 \pm 4.6^{*}$ & $8.0 \pm 3.7$ & 0.014 \\
\hline Weekly training (h/week) & $3.5(1.0)$ & $3.0(0.1)$ & $3.5(1.0)$ & 0.280 \\
\hline$\sum 3 \mathrm{SFT}(\mathrm{mm})$ & $56.3 \pm 16.4$ & $57.2 \pm 17.5$ & $55.3 \pm 15.2$ & 0.533 \\
\hline Body fat (\%) & $22.1 \pm 5.2$ & $22.5 \pm 5.4$ & $21.8 \pm 5.0$ & 0.512 \\
\hline Lean body mass (kg) & $45.4 \pm 4.5$ & $44.8 \pm 3,9$ & $46.0 \pm 5,0$ & 0.159 \\
\hline Fat mass $(\mathrm{kg})$ & $13.2 \pm 4.6$ & $13.4 \pm 5.0$ & $13.1 \pm 4.1$ & 0.769 \\
\hline Humerus diameter (mm) & $6.0(0.3)$ & $6.0(0.3)$ & $6.1(0.4)$ & 0.151 \\
\hline Femur diameter $(\mathrm{mm})$ & $8.8 \pm 0.5$ & $8.8 \pm 0.5$ & $8.8 \pm 0.5$ & 0.938 \\
\hline Contracted arm (cm) & $27.4 \pm 2.1$ & $27.4 \pm 2.0$ & $27.5 \pm 2.3$ & 0.840 \\
\hline Middle leg $(\mathrm{cm})$ & $35.3 \pm 2.1$ & $35.3 \pm 2.2$ & $35.3 \pm 2.1$ & 0.922 \\
\hline Endomorph & $4.5 \pm 1.1$ & $4.6 \pm 1.2$ & $4.5 \pm 1.1$ & 0.626 \\
\hline Mesomorph & $4.1 \pm 0.9$ & $4.2 \pm 0.9$ & $4.1 \pm 1.0$ & 0.701 \\
\hline Ectomorph & $2.0 \pm 1.0$ & $2.1 \pm 1.0$ & $2.0 \pm 0.9$ & 0.831 \\
\hline
\end{tabular}

BMl: body mass index; $\sum 3$ SFT: sum of the 3 skinfold thickness (tricipital, supra-liac and thigh); ${ }^{*} 1$ st semester (january to june) $\neq 2$ nd semester (july to december); ${ }^{\dagger} Q u i-$-square $\left(x^{2}\right)$; Significance level adopted $p<0,05$, Mann-Whitney $\mathrm{U}$ test for independent samples (weekly training and humerus diameter) and values expressed as median and interquartile range (25-75\%); Student's test for independent samples (other variables) and variables expressed as mean values and standard deviation (mean \pm SD). 
Table 2. Anthropometric characteristics of female futsal athletes according to the quartile (trimester) of birth.

\begin{tabular}{|c|c|c|c|c|c|c|}
\hline Variables & $\begin{array}{c}\text { All } \\
(n=115)\end{array}$ & $\begin{array}{c}\text { 1st quartile } \\
(n=36)\end{array}$ & $\begin{array}{c}\text { 2nd quartile } \\
\qquad(\mathrm{n}=23)\end{array}$ & $\begin{array}{c}\text { 3rd quartile } \\
\quad(n=32)\end{array}$ & $\begin{array}{l}\text { 4th quartile } \\
(n=24)\end{array}$ & $p$ \\
\hline Relative distribution $(\%)^{+}$ & 100 & 31.3 & 20.0 & 27.8 & 20.9 & 0.248 \\
\hline Age (years) & $22.0 \pm 3.9$ & $22.8 \pm 4.1$ & $22.1 \pm 4.3$ & $22.1 \pm 3.5$ & $20.5 \pm 3.3$ & 0.150 \\
\hline Body mass $(\mathrm{kg})$ & $58.6 \pm 7.6$ & $58.3 \pm 8.4$ & $57.8 \pm 6.2$ & $58.9 \pm 8.3$ & $59.3 \pm 6.7$ & 0.912 \\
\hline Height (cm) & $161.8 \pm 6.5$ & $161.1 \pm 6.6$ & $161.9 \pm 5.7$ & $162.4 \pm 7.6$ & $162.0 \pm 5.9$ & 0.887 \\
\hline BMI $\left(\mathrm{kg} / \mathrm{m}^{2}\right)$ & $22.3 \pm 2.1$ & $22.4 \pm 2.4$ & $22.1 \pm 1.9$ & $22.3 \pm 2.2$ & $22.5 \pm 1.8$ & 0.872 \\
\hline Menarche age (years) & $13.3 \pm 1.7$ & $13.2 \pm 1.7$ & $13.7 \pm 1.6$ & $13.4 \pm 2.1$ & $13.0 \pm 1.2$ & 0.582 \\
\hline Age of onset in futsal (years) & $13.0 \pm 3.6$ & $12.3 \pm 3.7$ & $13.3 \pm 3.7$ & $13.9 \pm 3.5$ & $12.8 \pm 3.1$ & 0.260 \\
\hline Practice time (years) & $9.0 \pm 4.3$ & $10.6 \pm 4.6^{*}$ & $8.9 \pm 4.4$ & $8.2 \pm 4.1$ & $7.7 \pm 3.3$ & 0.040 \\
\hline Weekly training (h/week) & $3.0(1.0)$ & $3.0(1.0)$ & $3.0(0.1)$ & $3.0(1.0)$ & $3.0(1.0)$ & 0.419 \\
\hline Sum 3SFT (mm) & $56.3 \pm 16.4$ & $56.8 \pm 16.7$ & $57.9 \pm 19.1$ & $53.9 \pm 16.5$ & $57.2 \pm 13.5$ & 0.804 \\
\hline Body fat (\%) & $22.1 \pm 5.2$ & $22.4 \pm 5.1$ & $22.7 \pm 5.8$ & $21.4 \pm 5.4$ & $22.5 \pm 4.3$ & 0.795 \\
\hline Lean body mass $(\mathrm{kg})$ & $45.4 \pm 4.5$ & $44.9 \pm 4$ & $44.5 \pm 3.8$ & $46.0 \pm 5.0$ & $45.9 \pm 5.1$ & 0.546 \\
\hline Fat mass $(\mathrm{kg})$ & $13.2 \pm 4.6$ & $13.4 \pm 5.3$ & $13.3 \pm 4.7$ & $12.9 \pm 4.7$ & $13.4 \pm 3.3$ & 0.971 \\
\hline Humerus diameter $(\mathrm{mm})$ & $6.1 \pm 0.3$ & $6.0 \pm 0.3$ & $6.2 \pm 0.3$ & $6.1 \pm 0.3$ & $6.0 \pm 0.3$ & 0.912 \\
\hline Femur diameter $(\mathrm{mm})$ & $8.8 \pm 0.5$ & $8.8 \pm 0.6$ & $8.8 \pm 0.3$ & $8.9 \pm 0.5$ & $8.8 \pm 0.4$ & 0.875 \\
\hline Contracted arm $(\mathrm{cm})$ & $27.4 \pm 2.1$ & $27.6 \pm 2.1$ & $27.1 \pm 1.7$ & $27.4 \pm 2.4$ & $27.6 \pm 2.1$ & 0.772 \\
\hline Middle leg $(\mathrm{cm})$ & $35.3 \pm 2.1$ & $35.4 \pm 2.4$ & $35.1 \pm 1.8$ & $35.3 \pm 2.4$ & $35.4 \pm 1.7$ & 0.927 \\
\hline Endomorph & $4.5 \pm 1.1$ & $4.6 \pm 1.1$ & $4.6 \pm 1.3$ & $4.4 \pm 1.2$ & $4.6 \pm 1.0$ & 0.801 \\
\hline Mesomorph & $4.1 \pm 0.9$ & $4.2 \pm 0.9$ & $4.1 \pm 0.9$ & $4.1 \pm 1.1$ & $4.1 \pm 0.9$ & 0.878 \\
\hline Ectomorph & $2.0 \pm 1.0$ & $2.0 \pm 1.1$ & $2.2 \pm 0.9$ & $2.1 \pm 1.0$ & $1.9 \pm 0.8$ & 0.819 \\
\hline
\end{tabular}

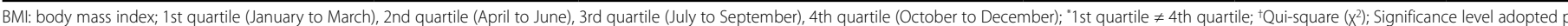

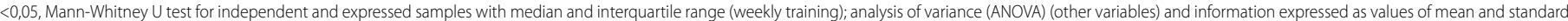
deviation (mean \pm SD).

Table 3. Distribution of female futsal athletes by game condition, quarter and semester of birth.

\begin{tabular}{c|c|c|c|c|c|c}
\hline \multicolumn{2}{c|}{} & \multicolumn{2}{c|}{ Backups } & \multicolumn{2}{c|}{ Starters } & \multirow{2}{*}{$\mathbf{p}$} \\
\cline { 3 - 7 } \multicolumn{2}{c|}{} & $\mathbf{n}$ & $\mathbf{\%}$ & $\mathbf{n}$ & $\%$ & \\
\hline \multirow{3}{*}{ Semester } & 1st & 31 & 56.4 & 28 & 46.7 & \multirow{2}{*}{0.352} \\
\cline { 2 - 6 } & 2nd & 24 & 43.6 & 32 & 53.3 & \\
\hline \multirow{4}{*}{ Quartile } & Q1 & 17 & 30.9 & 19 & 31.7 & \\
\cline { 2 - 6 } & Q2 & 14 & 25.5 & 9 & 15.0 & \multirow{3}{*}{0.744} \\
\cline { 2 - 6 } & Q3 & 12 & 21.8 & 20 & 33.3 & \\
\cline { 2 - 6 } & Q4 & 12 & 21.8 & 12 & 20.0 & \\
\hline
\end{tabular}

Qui-square $\left(x^{2}\right) ; \mathrm{Q} 1$ = 1st quartile (January to March); Q2 = 2nd quartile (April to June); Q3 = 3rd quartile (July to September); $Q 4=4$ th quartile (October to December); Significance level of $p<0.05$.

condition of starters or backups of the teams investigated. The backup athletes represented $56 \%$ of the sample, while the starters represented $47 \%$ of the athletes born in the first semester. When separated by birth quartile, the athletes born in the first three months of the year constituted $31 \%$ and $32 \%$ against $22 \%$ and $20 \%$ of backups and starters, respectively.

\section{DISCUSSION}

In the present study the ERA was analyzed in the distribution, in the anthropometric profile and in the ownership of Brazilian female futsal athletes, representatives of 10 professional teams of high competitive level. The results showed that the distribution of the athletes by the year of birth was not influenced by the relative age, since there was uniformity in the representation of the athletes for the year of selection, both per semester and per quartile of birth, In addition, athletes born in the first months of the year did not demonstrate significantly greater physical development (anthropometric profile) nor were they represented in the conditions of the participants participating in the competition more than the players born in the last months of the year. However, it was observed that athletes born in the first months of the year presented significantly longer practice time than athletes born in the last months of the selection year, both per semester ( $9.9 \pm 4.6$ vs. $8.0 \pm 3.7$ years), and by quartile (1st quartile: 10.6 \pm 4.6 vs. 4 th quartile: $7.7 \pm 3.3$ years). However, this greater "experience" did not translate in this study into any advantage investigated (physical structure, entitlement) for the athletes with greater time of practice.

Although evidence indicates that athletes born in the first months of the year of selection are more represented in competitions because they present advantages coming from physical maturation, 8,12 in the present study there were no differences in the age of menarche, either per semester ( $1 \mathrm{st}=13.4 \pm 1.7 \mathrm{vs}$. $2 \mathrm{nd}=13.2 \pm 1.8$ years, respectively) or birth quartile $(\mathrm{Q} 1=13.2 \pm 1.7$ vs. $\mathrm{Q} 2=13.7 \pm 1.6 \mathrm{vs} . \mathrm{Q} 3=13.4 \pm 2.1 \mathrm{vs}$. $\mathrm{Q} 4=13.0 \pm 1.2$ years, respectively). In addition, there were no differences for the year of initiation in the modality per semester ( $1 \mathrm{st}=12.6 \pm 3.7$ vs. 2 nd $=13.4 \pm 3.4$ years $)$ or by birth quartile $(\mathrm{Q} 1=12.3 \pm 3.7$ vs. Q2 $=13.3 \pm 3.7$ vs. Q3 = $13.9 \pm 3.5$ vs. Q4 = $12.8 \pm 3.1$ years, respectively). This information (year of menarche and beginning of futsal) suggests that the athletes in this study either were matured or matured in the same year they started in futsal, suggesting that maturation may not have influenced the recruitment of these athletes to the competitive condition that they were at.

Other variables related to physical characteristics (body mass, height, bone and muscle development, muscle mass and fat mass, somatotype), which are considered as protagonists in the ERA in sport, 8,9 in our sample, the athletes born in the first months were absolutely similar to the athletes born in the last months of the same year (semester and quartile). However, the cross-sectional approach of the present study does not rule out the possibility of presenting differences in the physical structure observed at the present age, at the beginning of the sports career.

Influence of the ERA on the distribution of athletes born in the first months of the year was demonstrated in several modalities, such as soccer, ${ }^{11,24,25}$ futsal, ${ }^{26}$ tennis, ${ }^{27}$ basketball, ${ }^{9}$ baseball, ${ }^{28}$ ice hockey ${ }^{29}$ and many other sports. ${ }^{8}$ However, the vast majority of these studies was limited to investigating male samples, with only a small portion using women. ${ }^{30}$ The present study, on the occurrence of ERA in adult female futsal athletes is one of the few researches with this public and modality. The results are compatible with preliminary studies and reinforce previous evidence, which demonstrated none or minor ERA in female athletes. ${ }^{16,17,31}$ In a study of elite female athletes in France, ERA was not 
shown for soccer, basketball and handball. ${ }^{10}$ Recently, data from 655 athletes participating in the 12th European Youth Olympics Festival were analyzed and a significant ERA was observed among boys, but not among girls. Data on youth soccer athletes from the US Olympic development program revealed only discrete ERA among girls. ${ }^{16}$ The ERA was also investigated in 5229 university students of sports sciences (non-athletes). The study found that most men were born in the first half of the year, with the exception of women, who had a balanced distribution compared to the date of birth.

Contrary to our results, the ERA was confirmed in Spanish women's football at almost all competitive levels, with an excessive representation of female players born in the first quartile of the year. In addition, the findings revealed that the ERA was more pronounced as the level of competition increased ${ }^{18}$, which was not confirmed in another study, that identified a"reversal of the ERA" in the junior leagues to the elite in male hockey. ${ }^{32}$ However, evidence has indicated that sport ERA is mediated by age and sex, ${ }^{1,15,33}$ in which the occurrence of athletes born in the first months of the year in one sport is less frequent among female athletes, older athletes or both. ${ }^{16,33}$

There are speculations about the reasons for minor ERA in female athletes that include interactions of social, cultural, maturational and biological aspects, sports start, performance, selection criteria and sports popularity. ${ }^{10,16,33}$ Among the probable causes, the hypothesis of maturational selection is considered a fundamental mechanism. ${ }^{15}$ However, Hancock, Adley and Côté 14 emphasize that the genesis, perpetuation and amplification of the ERA in sports are determined only by social agents (parents and technicians / teachers). They are knowledge drawn from psychological and sociological theories, based on the effects of Matthew, Pygmalion and Galatea, which, although they were tested in sport, were not applied in the context of relative age. These theories form an integrated theoretical model that could help in understanding the role of social agents in the ERA in sport, since it is the social agents that ultimately interpret mechanisms such as maturity, size and sportsmanship. ${ }^{14}$

Among the limitations that should be highlighted in the development of this study, we can highlight the cross-sectional approach, which does not make it possible to compare anthropometric characteristics at the beginning of the participants'career, as well as the number of participants in the study ( $n=115)$, since most studies available in the literature used larger samples. However, specifically in this respect, it is interesting to note that the athletes of the present study constitute the futsal elite for the adult category, with most of the athletes integrating the Brazilian team.

\section{CONCLUSIONS}

There was no ERA in the distribution, anthropometric profile and ownership between athletes born from January to June and those born from July to December who participated in the XX Brazilian Cup of Women's Futsal Clubs in Criciúma 2011. On the other hand, athletes born in months have shown longer practice than those born in the last months of the year.

All authors declare no potential conflict of interest related to this article

AUTHORS' CONTRIBUTIONS: Each author made significant individual contributions to this manuscript. SAF and VMRW: writing the work and critical review of its intellectual content; approval of the final version of the manuscript; and TGC: review of the manuscript; and MRQ: substantial contribution to the conception; design; writing and critical review of its intellectual content.

\section{REFERENCES}

1. Müller L, Hildebrandt C, Schnitzer M, Raschner C. The Role of a Relative age effect in the 12th Winter European Youth Olympic festival in 2015. Percept Mot Skills. 2016;122(2):701-18.

2. Barnsley RH, Thompson AH, Barnsley PE. Hockey success and birthdate: the relative age effect. Can Assoc Health Phys Educ Recr Journal. 1985;51(8):23-8.

3. Werneck FZ, Lima JR, Coelho EF, Matta MO, Figueiredo AJ. Efeito da idade relativa em atletas olímpicos de triatlo. Rev Bras Med Esporte. 2014: 20(5):394-7.

4. Silva T, Garganta J, Brito J, Cardoso F, Teoldo I. Influência do efeito da idade relativa sobre o desempenho tático de atletas de futebol da categoria sub-13. Rev Bras Cienc Esporte. 2018;40(1):54-61.

5. Altimari JM, Altamari LR, Paula L, Bortolotti H, Pasquarelli BN, Ronque ER, et al. Distribuição do mês de nascimento dos jogadores das seleções brasileiras de futebol. Rev Andal Med Deporte. 2011;4(1):13-6.

6. Barnsley RH, Thompson AH. Birthdate and success in minor hockey: The key to the NHL. Canad J Behav Sci, 1988;20(2):167-76.

7. Bisanz J, Morrison FJ, Dunn M. Effects of age and schooling on the acquisition of elementary quantitative skills. Dev Psychol. 1995;31(2):221-36.

8. Musch J, Grondin S. Unequal competition as an impediment topersonal development: a review of the relative age effect in sport. Dev Review. 2001;21(2):147-67.

9. Delorme N, Raspaud M. The relative age effect in young French basketball players: a study on the whole population. Scand J Med Sci Sports. 2009;19(2):235-42.

10. Delorme N, Boiché J, Raspaud M. The relative age effect in elite sport: the French case. Res Q Exerc Sport. 2009;80(2):336-44.

11. Helsen WF, van Winckel J, Williams AM. The relative age effect in youth soccer across Europe. J Sports Sci. 2005;23(6):629-36.

12. González Aramendi JM. Mes de nacimiento y éxito en el fútbol. Estudios del efecto relativo de la edad en el fútbol guipuzcoano. Osasunaz. 2004;6:159-84.

13. Delorme N, Chalabaev A, Raspaud M. Relative age is associated with sport dropout: evidence from youth categories of French basketball. Scand J Med Sci Sports. 2011;21(1):120-8.

14. Hancock DJ, Adler AL, Côté J. A proposed theoretical model to explain relative age effects in sport. Eur J Sport Sci. 2013;13(6):630-7.

15. Brazo-Sayavera J, Martínez-Valencia MA, Müller L, Andronikos G, Martindale RJ. Identifying talented track and field athletes: the impact of relative age effect on selection to the Spanish National Athletics Federation training camps. J Sports Sci. 2017;35(22):2172-8.

16. Vincent J, Glamser FD. Gender differences in the relative age effectamong US Olympic Development Program youth soccer players. J Sports Sci. 2006;24(4):405-13.
17. Silva DC, Padilha MB, Costa IT. Relative age effect in world cups male and female inside categories U-20 and professional. J Phys Education. 2015;26(4):567-72.

18. Sedano $S$, Vaeyens $R$, Redondo JC. The relative age effect in spanish female soccer players. Influence of the competitive level and a playing position. J Hum Kinet. 2015;46:129-37.

19. Okazaki FH, Keller B, Fontana FE, Gallagher JD. The relative age effect among female Brazilian youth volleyball players. Res Q Exerc Sport. 2011;82(1):135-9.

20. Marfell-Jones M, Olds T, Stewart A, Carter L. International standards for anthropometric assessment. Sydney: UNSW Press, 2006

21. Jackson AS, Pollock ML, Ward A. Generalized equations for predicting body density of women. Med Sci Sports Exerc. 1980;12(3):175-81.

22. Siri WE. Body composition from fluid spaces and density: analysis of methods. In: Brozek J, Henschel A. Techniques for measuring body composition. Washington: National Academy Sciences. 1961.p.223-4

23. Heath BH, Carter JEL. A modified somatotype method. Am J Phys Anthropol. 1967;27(1):57-74.

24. Carli GC, Luguetti CN, Ré AH, Böhme MT. Efeito da idade relativa no futebol. Rev Bras Ci Mov. 2009 17(3):25-31.

25. Salinero JJ, Pérez B, Burillo P, Lesma ML. Relative age effect in european professional football. Analysis by position. J Hum Sport Exerc. 2013;8(4):966-73.

26. Penna EM, Moraes LC. Efeito relativo da idade em atletas brasileiros de futsal de alto nível. Motriz: J Phys Educ. 2010;16(3):658-63.

27. Edgar S, O'Donoghue P. Season of birth distribution of elite tennis players. J Sports Sci. 2005;23(10):1013-20.

28. Tompson AH, Barnsley RH, Stebelsky G. Born to Play Ball. The relative age effect and major league baseball. Sociol Sport J. 1991;8(2):146-51.

29. Sherar LB, Baxter-Jones AD, Faulkner RA, Russell KW. Do physical maturity and birth date predict talent in male youth ice hockey players? J Sports Sci. 2007;25(8):879-86.

30. Cobley S, Baker J, Wattie N, McKenna J. Annual age-grouping and athlete development: a meta-analytical review of relative age effects in sport. Sports Med. 2009;39(3):235-56.

31. Saavedra-Garcia M, Gutierrez-Aguilar O, Sa-Marques P, Fernandez-Romero JJ. Efecto de la edad relativa en el atletismo español. Cuad Psicol Deporte. 2016;16(1):275-86.

32. Gibbs BG, Jarvis JA, Dufur MJ. The rise of the underdog? The relative age effect reversal among Canadianborn NHL hockey players: A reply to Nolan and Howell. Int Rev Sociol Sport. 2012;47(5):644-9.

33. Hollings SC, Hume PA, Hopkins WG. Relative-age effect on competition outcomes at the World Youth and World Junior Athletics Championships. Eur J Sport Sci. 2014;14(Suppl 1):S456-61. 